\title{
An Investigation of the Role of Microsomal Oxidative Metabolism in the in Vivo Genotoxicity of 1,2-Dichloroethane ${ }^{1}$
}

\author{
RICHARD D. STORER ${ }^{2}$ AND RORY B. CONOLLY \\ Toxicology Research Laboratory, Department of Environmental and Industrial Health, School of Public Health, \\ University of Michigan, Ann Arbor, Michigan 48109-2029
}

Received March 31, 1984; accepted August 17, 1984

\begin{abstract}
An Investigation of the Role of Microsomal Oxidative Metabolism in the in Vivo Genotoxicity of 1,2-Dichloroethane. StORER, R. D., AND CONOLlY, R. B. (1985). Toxicol. Appl. Pharmacol. 77, 36-46. In vitro studies have demonstrated that two different metabolic pathways, glutathione conjugation mediated by the glutathione $S$-transferases and microsomal oxidation, may be involved in the genotoxicity and carcinogenicity of 1,2-dichloroethane (DCE). To evaluate the importance of microsomal oxidative metabolism in the bioactivation of DCE in vivo, male $\mathrm{B} \mathrm{C}_{3} \mathrm{~F}_{1}$ mice were pretreated with piperonyl butoxide (PIB), an inhibitor of microsomal oxidative metabolism, and the effect of this pretreatment on the extent of hepatic DNA damage produced by DCE was determined $4 \mathrm{hr}$ after DCE administration. The in vivo genotoxicity of 2-chloroethanol, a product of the microsomal oxidative metabolism of DCE, was also investigated. Hepatic DNA damage was measured with a sensitive, alkaline DNA unwinding assay for the presence of single-strand breaks and alkali-labile lesions in DNA. Pretreatment of mice with PIB to inhibit microsomal oxidative metabolism significantly potentiated the hepatic DNA damage observed $4 \mathrm{hr}$ after a single, $200-\mathrm{mg} / \mathrm{kg}$, ip dose of DCE. Treatment of mice with single, ip doses of 2-chloroethanol as high as $1.2 \mathrm{mmol} / \mathrm{kg}$ failed to produce any evidence of single-strand breaks and/or alkali-labile lesions in hepatic DNA. When diethyl maleate (DEM) was used to deplete hepatic glutathione levels prior to administration of 2-chloroethanol, the acute hepatotoxicity of 2-chloroethanol was potentiated but again there was no evidence of hepatic DNA damage. These results indicate that microsomal, oxidative metabolism of DCE to 2-chloroethanol and/or 2 chloroacetaldehyde is not responsible for the hepatic DNA damage observed in these studies after DCE administration. (c) 1985 Academic Press, Inc.
\end{abstract}

1,2-Dichloroethane (DCE) is an economically important, chlorinated, aliphatic hydrocarbon used primarily in the production of vinyl chloride and other halogenated organics and as a solvent, gasoline additive, and component of fumigants. The National Cancer Institute (USDHEW, 1978) has determined that DCE is carcinogenic to Osborne-Mendel rats and $\mathrm{B}_{6} \mathrm{C} 3 \mathrm{~F}_{1}$ mice when administered

\footnotetext{
' Supported by NIH Grant 5 T32 ES07062.

${ }^{2}$ Present address and to whom all correspondence should be addressed: Merck Institute for Therapeutic Research, Merck Sharp and Dohme Research Laboratories, Building 44-1, West Point, Pa. 19486.
}

chronically by gavage. A second bioassay of DCE for possible carcinogenicity by the inhalation route of exposure failed, however, to produce any evidence for the carcinogenicity of DCE in Sprague-Dawley rats or Swiss mice (Maltoni et al., 1980). The carcinogenic potential of DCE has, therefore, remained somewhat speculative and may, as the results of the bioassays suggest, be dependent on the strains of test animals or the route of exposure (Hooper et al., 1980).

Positive results from several short-term in vitro test systems for mutagenicity (Rannug, 1980; Guengerich et al., 1980; van Bladeren 
et al., 1981; Tan and Hsie, 1981) and primary DNA damage (Banerjee and van Duuren, 1979; Banerjee et al., 1980; Guengerich et al., 1980; Perocco and Prodi, 1981) have provided further evidence of the carcinogenic potential of DCE. More recent studies have also confirmed the genotoxic potential of DCE in vivo (Reitz et al., 1982; Storer et al., 1982, 1984; Storer and Conolly, 1983). The in vitro studies cited above indicated that DCE requires metabolic activation to exhibit genotoxic activity and identified two different metabolic pathways, glutathione conjugation and microsomal oxidation, as potentially significant sources of mutagenic and/or carcinogenic metabolites from DCE. The glutathione $S$-transferase-mediated conjugation of DCE with glutathione produces reactive compounds, presumably half-sulfur mustards, which have been shown to be mutagenic toward Salmonella typhimurium strains TA 1535 and TA 100 (Rannug et al., 1978; Guengerich et al., 1980; van Bladeren et al., 1981). The results from these mutagenicity studies and an in vitro DNA binding study (Guengerich et al., 1980) have suggested that the primary route of bioactivation for DCE may be the glutathione conjugation pathway.

In vitro DNA binding experiments with DCE (Banerjee and van Duuren, 1979; Banerjee et al., 1980; Guengerich et al., 1980) have, however, also provided evidence for the involvement of microsomal oxidative metabolism in the bioactivation of DCE to a genotoxic metabolite. 2-Chloroacetaldehyde, which is mutagenic in the Ames test without metabolic activation (McCann et al., 1975), is believed to be the active metabolite of DCE formed by this pathway. DNA binding studies in vitro have shown that 2-chloroacetaldehyde reacts directly with adenine and cytosine bases to form cyclic etheno adducts (Barrio et al., 1972; Lee and Wetmur, 1973; Guengerich et al., 1981). Further evidence for the possible importance of 2-chloroacetaldehyde binding to DNA comes from studies demonstrating the presence of $3-N^{4}$ ethenodeoxycytidine (Green and Hathway,
1978) and 7-N-(2-oxocthyl)guanine (Laib et al., 1981) in hydrolysates of DNA from rats exposed to vinyl chloride. Vinyl chloride metabolism in vitro has been shown to result in 2-chloroacetaldehyde production by rearrangement of 2-chloroethylene oxide (Bonse et al., 1975), a product of microsomal oxidative metabolism of vinyl chloride (Barbin et al., 1975). More recently, 2-chloroacetaldehyde pretreatment of nucleotide polymers has been shown to induce errors during DNA synthesis in vitro (Hall et al., 1981). There is, therefore, considerable evidence to suggest that microsomal oxidative metabolism of DCE to 2-chloroacetaldehyde may also be involved in the genotoxicity and carcinogenicity of DCE.

Recent sudies in our laboratory have shown that DNA single-strand breaks and/or alkalilabile lesions can be detected in hepatic DNA isolated from mice $4 \mathrm{hr}$ after treatment with a single, po or ip dose of DCE (Storer et al., 1982; Storer and Conolly, 1983). This type of DNA damage was not, however, detectable in mice exposed by inhalation to concentrations of DCE as high as $500 \mathrm{ppm}$ for $4 \mathrm{hr}$ (Storer et al., 1984). In the present study, the rolc of microsomal oxidative metabolism of DCE in the formation of the reactive metabolite(s) responsible for this type of hepatic DNA damage was investigated in vivo in two different ways. First, the effect of a potent inhibitor of microsomal oxidative metabolism, piperonyl butoxide (PIB), on the hepatic DNA damage produced by DCE was studied. Second, the potential of 2-chloroethanol to produce single-strand breaks and/or alkalilabile lesions in hepatic DNA from mice treated in vivo was investigated. 2-Chloroethanol is metabolized by alcohol dehydrogenases to 2-chloroacetaldehyde (Blair and Valee, 1966; Johnson, 1967) and was employed in these studies as a means of generating 2chloroacetaldehyde intracellularly in vivo. The acute toxicity of 2-chloroacetaldehyde in vivo and evidence of its reactivity at the site of administration (Lawrence et al., 1972) indicated that it would not be feasible to inves- 
tigate the in vivo genotoxicity of this compound directly.

\section{METHODS}

Animals. Male $\mathrm{B}_{6 \mathrm{C}} 3 \mathrm{~F}_{1}$ mice were purchased from Charles River Breeding Laboratories, Inc., Portage, Michigan, or were bred in our laboratories from $\mathrm{C} 3 \mathrm{H}$ male and C57BL female mice obtained from Charles River Breeding Laboratories, Inc. Mice were 6 to 9 weeks of age at the timc of experiments and had been maintained in our laboratory for at least 3 weeks prior to use. Mice were housed 8 to 10 per cage, bedded in soft wood chips, and fed Purina rodent chow and water ad libitum until the morning of experiments. Animal rooms were maintained at 22 to $24^{\circ} \mathrm{C}$ with a $12 \mathrm{hr}$ light-dark cycle. DCE and PIB were administered ip in corn oil in a constant volume of 5 and $1 \mathrm{ml} / \mathrm{kg}$, respectively. 2-Chloroethanol was dissolved in $0.85 \%$ $\mathrm{NaCl}$ and administered ip in a constant volume of $5 \mathrm{ml} /$ kg. Diethyl maleate (DEM) was administered ip (neat). Carbon tetrachloride $\left(\mathrm{CCl}_{4}\right)$ was given ip in corn oil in a constant volume of $5 \mathrm{ml} / \mathrm{kg}$.

Chemicals. DCE (glass distilled) was purchased from MCB Manufacturing Chemists, Inc., Cincinnati, Ohio. Its purity was checked by gas chromatography (flame ionization detector) and found to be greater than $99.9 \%$. PIB was obtained from ICN Pharmaceuticals, Plainview, New York. 2-Chloroethanol and diaminobenzoic acid dihydrochloride were purchased from Aldrich Chemicals, Milwaukee, Wisconsin. DEM, glutathione reductase, reduced glutathione (GSH), oxidized glutathione (GSSG), NADH, and NADPH were all obtained from the Sigma Chemical Company, St. Louis, Missouri. Hexobarbital was purchased from Winthrop Stearns Inc., New York, New York, and 2-vinylpyridine from Fluka AG, Buchs, Switzerland. The hydroxylapatite (Bio-Gel HTP, DNA grade) was obtained from Bio-Rad Laboratories, Richmond, California.

Hexobarbital sleeping time. Hexobarbital (free acid, $125 \mathrm{mg}$ ) was added to $1.5 \mathrm{ml}$ of $0.85 \% \mathrm{NaCl}$, and 5- to $25 \mu \mathrm{l}$ aliquots of $5.0 \mathrm{~N} \mathrm{NaOH}$ were added until the hexobarbital dissolved. The solution was then diluted to $2.0 \mathrm{ml}$. Mice were injected ip with $2.0 \mathrm{ml} / \mathrm{kg}$ of this solution $(125 \mathrm{mg} / \mathrm{kg})$, and the hexobarbital sleeping time was measured as the time from loss of the righting reflex to its restoration, as previously described (Vesell, 1968).

Hepatic glutathione levels. Oxidized glutathione (GSSG) and total glutathione (GSSG and GSH) per gram of liver tissue were determined by a glutathione reductase recycling assay (Tietze, 1969). The procedure, described below, is a modification of the techniques developed by Griffith (1980) and Akerboom and Sies (1981). Mice treated as described in the text were killed by cervical dislocation and the livers removed and homogenized in $9 \mathrm{vol}$ of cold $1.0 \mathrm{M} \mathrm{HClO}_{4}$ and $2.0 \mathrm{mM}$ EDTA- $\mathrm{Na}_{2}$.
Homogenates were centrifuged at $3500 \mathrm{~g}$ for $15 \mathrm{~min}$ at $4^{\circ} \mathrm{C}$ and the supernatant fractions diluted either $1 / 10$ for determination of GSSG or 1/100 for determination of total glutathione (GSH and GSSG). Aliquots ( $690 \mu \mathrm{l}$ ) of these dilutions were then transferred to separate tubes containing $410 \mu \mathrm{l}$ of $2.0 \mathrm{M} \mathrm{KOH}$ and $0.3 \mathrm{M}$ Hepes; the precipitate was pelleted by centrifugation for $15 \mathrm{~min}$ at $3500 \mathrm{~g}$. For the determination of GSSG, $10.5 \mu \mathrm{l}$ of 2 vinylpyridine was added to each tube with the $2.0 \mathrm{M}$ $\mathrm{KOH}, 0.3 \mathrm{M}$ Hepes to derivatize the GSH. The supernatant fraction in each tube was then assayed for glutathione by the glutathione reductase recycling assay. An aliquot $(700 \mu \mathrm{l})$ of $0.1 \mathrm{M}$ sodium phosphate, $5.0 \mathrm{~mm}$ EDTA- $\mathrm{Na}_{2}$ buffer, $\mathrm{pH} 7.5$, containing $0.3 \mathrm{~mm}$ NADPH, was transferred to a $1.5-\mathrm{ml}$ cuvette containing $20 \mu \mathrm{l}$ of $3.8 \mathrm{~mm} 5,5^{\prime}$-dithiobis-2-nitrobenzoic acid (DTNB) in 0.1 M sodium phosphate, 5 mM EDTA- $\mathrm{Na}_{2}$ buffer, $\mathrm{pH} 7.5$, and $200 \mu \mathrm{l}$ of neutralized supernatant fraction. To start the assay, $40 \mu \mathrm{l}$ of GSH reductase (12.5 units $/ \mathrm{ml}$ in 0.1 M sodium phosphate, $50 \mathrm{mM}$ EDTA- $\mathrm{Na}_{2}$ buffer, $\mathrm{pH} 7.5$ ) was added and the absorbance at $412 \mathrm{~nm}$ monitored for $5 \mathrm{~min}$ at $25^{\circ} \mathrm{C}$. The glutathione content of the samples was then determined from standard curves for the rate of change of the absorbance at $412 \mathrm{~nm}$ for standards containing known amounts of GSSG or GSH. The GSH concentration in the samples was calculated as the difference between the total glutathione (GSH and GSSG) and oxidized glutathione (GSSG) per gram of tissue.

Acute toxicity. To assess the acute toxicity of DCE and 2-chloroethanol alone and with PIB and DEM pretreatments, respectively, mice were treated as described in the text and killed $24 \mathrm{hr}$ later. Feed but not water was removed during the interval between dosing and termination. Liver and kidneys were removed and weighed; blood was drawn for determination of serum enzyme levels. L-Iditol dehydrogenase (IDH, sorbitol dehydrogenase, EC 1.1.1.14) activity in serum was analyzed according to the method described by Conolly $e t$ al. (1979) and serum alanine aminotransferase (AAT, EC 2.6.1.2) activity by the method of Wroblewski and LaDue (1956).

In vivo-in vitro genotoxicity assay. In vivo genotoxicity was determined with a sensitive in vivo-in vitro alkaline DNA unwinding assay for the presence of single-strand breaks and alkali-labile sites in hepatic DNA (Storer and Conolly, 1983, 1984). Mice were treated as described in the text and killed $4 \mathrm{hr}$ later by cervical dislocation. Hepatic DNA damage measured as single-strand breaks in alkali has previously been shown to be maximal $4 \mathrm{hr}$ after administration of a genotoxic 1,2-dihaloethane, 1,2dibromoethane (Nachtomi and Sarma, 1977). Livers were removed and suspensions of hepatic nuclei prepared by gently mincing livers in cold $0.075 \mathrm{M} \mathrm{NaCl}$ and 0.024 M EDTA-Na $a_{2}, \mathrm{pH}$ 7.5. The presence of single-strand breaks and/or alkali-labile lesions in the hepatic DNA was then determined by alkaline DNA unwinding and hydroxylapatite batch chromatography as previously described (Storer and Conolly, 1983, 1984). For each 
sample of nuclei, assayed in duplicate, the fraction of the total DNA recovered which eluted from the hydroxylapatite as double-stranded DNA was calculated. Results for each animal were then expressed as a percentage of the mean value for the fraction of the DNA that is double stranded in the control group and results for each group as the mean and standard deviation of these percentages.

Statistical analysis. Mean and standard deviations were calculated for each experimental group. Significance testing was by one-way analysis of variance with multiple comparisons by the Bonferroni method (Neter and Wasserman, 1974). Statistical significance was assumed at the $p \leqslant 0.05$ level.

\section{RESULTS}

Hexobarbital sleeping times have previously been shown to be a convenient measure of microsomal cytochrome $P$-450-mediated, monooxygenase activity in vivo (Conney et al., 1960). Results presented in Table 1 indicate that PIB, at the dose levels employed in these studies, significantly inhibited microsomal oxidative metabolism of hexobarbital as evidenced by the approximately 10 -fold increase in observed hexobarbital sleeping times. Similar results for the effect of PIB on hexobarbital sleeping times in male mice have been reported earlier (Kamienski and Murphy, 1971). Whereas DCE metabolism has previously been shown to be dependent on cytochrome P-450-mediated monooxygenase activity (Guengerich et al., 1980) and

TABLE 1

Effect of Piperonyl Butoxide Pretreatment on HeXobarbital SLeEPING Times

\begin{tabular}{lc}
\hline Pretreatment $^{a}$ & $\begin{array}{c}\text { Hexobarbital sleeping } \\
\text { time }^{b} \text { (min) }\end{array}$ \\
\hline Corn oil & $69 \pm 9$ \\
PIB & $659 \pm 135^{c}$ \\
\hline
\end{tabular}

${ }^{a}$ PIB $(200 \mathrm{mg} / \mathrm{kg})$ or corn oil was administered ip to 3 male B6C3F, mice per group $1 \mathrm{hr}$ before hexobarbital.

${ }^{b}$ Hexobarbital $(125 \mathrm{mg} / \mathrm{kg}$ ) was administered ip. Values are $\bar{x} \pm$ SD.

'Significantly different from control $(p \leqslant 0.05)$ by one-way analysis of variance (Neter and Wasserman, 1974). to be inhibited by the classic cytochrome $P$ 450 inhibitors, SKF-525A and metyrapone (Guengerich et al., 1980), these results indicate that the PIB pretreatment employed in these studies would be expected to have significantly inhibited microsomal oxidative metabolism of DCE in vivo.

The effect of PIB pretreatment on hepatic glutathione levels was also investigated in preliminary experiments to determine if the previously reported depletion of hepatic glutathione by PIB in mice (James and Harbison, 1982) would be observed at the dose levels required to inhibit microsomal oxidative metabolism. No significant changes in hepatic glutathione levels were observed, however, in groups of three mice 1.5, 3.0, or $4.5 \mathrm{hr}$ after a single, $200-\mathrm{mg} / \mathrm{kg}$ dose of PIB. These results indicated that hepatic glutathione depletion would not be a significant confounding factor in the genotoxicity experiments.

Acute hepatotoxicity may under certain circumstances be a confounding factor in hepatic DNA damage studies where the endpoint employed is single-strand breaks in alkali (Sina et al., 1983). We have previously found that a single, ip dose of $\mathrm{CCl}_{4}(25 \mu \mathrm{l} /$ $\mathrm{kg}$ ) which produces evidence of severe hepatotoxicity at $24 \mathrm{hr}$ did not have any significant effect on DNA strand integrity as early as 4 $\mathrm{hr}$ after treatment (Storer, et al., 1984). Nevertheless, the acute hepatotoxicity of the treatment regimens employed in the in vivo genotoxicity studies reported here was investigated in separate experiments. Results presented in Table 2 indicate that neither DCE nor PIB, alone or in combination, was acutely hepatotoxic at the doses employed in these studies. Liver weight to body weight ratios were elevated after PIB treatment but this effect, reported previously (Philpot and Hodgson, 1971), is belicved to be due to the inductive effect of PIB on microsomal enzymes rather than to acute hepatotoxicity.

The effect of PIB pretreatment on the extent of hepatic DNA damage produced by DCE is shown in Table 3. Administration of PIB alone did not produce any evidence of 
TABLE 2

Acute Toxicity of 1,2-Dichloroethane: Effect of Pretreatment with Piperonyl Butoxide“

\begin{tabular}{|c|c|c|c|c|c|}
\hline Compound & Pretreatment & $\begin{array}{l}\text { Liver } \\
\text { weight }^{b}\end{array}$ & $\begin{array}{l}\text { Serum IDH }{ }^{c} \\
(\mathrm{IU} / \mathrm{I})\end{array}$ & $\begin{array}{l}\text { Serum AAT } \\
\text { (IU/l) }\end{array}$ & $\begin{array}{l}\text { Kidney } \\
\text { weight }^{b}\end{array}$ \\
\hline Corn oil & Sham & $4.44 \pm 0.34$ & $9.8 \pm 1.2$ & $7.3 \pm 1.5$ & $1.47 \pm 0.10$ \\
\hline Corn oil & $\begin{array}{r}\mathrm{PIB}, 200 \\
\mathrm{mg} / \mathrm{kg}\end{array}$ & $5.16 \pm 0.23^{d}$ & $17.8 \pm 12.6$ & $10.9 \pm 8.1$ & $1.53 \pm 0.13$ \\
\hline $\begin{array}{c}\text { DCE, } 200 \\
\mathrm{mg} / \mathrm{kg}\end{array}$ & Sham & $4.40 \pm 0.14$ & $10.8 \pm 2.6$ & $4.6 \pm 0.8$ & $1.41 \pm 0.02$ \\
\hline $\begin{array}{c}\mathrm{DCE}, 200 \\
\mathrm{mg} / \mathrm{kg}\end{array}$ & $\begin{array}{r}\mathrm{PIB}, 200 \\
\mathrm{mg} / \mathrm{kg}\end{array}$ & $5.18 \pm 0.22^{d}$ & $8.8 \pm 0.6$ & $6.7 \pm 1.0$ & $1.52 \pm 0.06$ \\
\hline $\begin{array}{c}\mathrm{CCl}_{4}, 25 \\
\mu \mathrm{l} / \mathrm{kg}\end{array}$ & - & $6.23 \pm 0.53^{d}$ & $5821.0 \pm 1565.5^{d}$ & $2590.0 \pm 731.9^{d}$ & $1.51 \pm 0.09$ \\
\hline
\end{tabular}

${ }^{a} \mathrm{~B} 6 \mathrm{C} 3 \mathrm{~F}$, male mice were killed $24 \mathrm{hr}$ after ip administration of DCE or corn oil. PIB was injected ip 1 hr before DCE or corn oil. All values are $\bar{x} \pm$ SD for 3 to 5 mice per group.

${ }^{b}$ Organ weight per $100 \mathrm{~g}$ body wt.

${ }^{c}$ IDH, L-iditol dehydrogenase (EC 1.1.1.14); AAT, alanine aminotransferase (EC 2.6.1.2).

${ }^{d}$ Significantly different from control $(p \leqslant 0.05)$ by one-way analysis of variance with multiple comparisons by the Bonferroni method (Neter and Wasserman, 1974).

DNA strand breaks in alkali but, as previously reported (Storer and Conolly, 1983), DCE alone significantly decreased the fraction of

TABLE 3

IN VIVO GENOTOXICITY OF 1,2-DICHLOROETHANE: Effect of Pretreatment with Piperonyl Butoxide ${ }^{a}$

\begin{tabular}{llclc}
\hline Compound & $\begin{array}{c}\text { Pretreat- } \\
\text { ment }\end{array}$ & $\begin{array}{c}\text { Fraction double- } \\
\text { stranded DNA } \\
\text { (\% of control) }\end{array}$ & $\begin{array}{c}\% \\
\text { Change }^{c}\end{array}$ \\
\hline Corn oil & Corn oil & $100.0 \pm 3.3$ & $(12)$ & - \\
Corn oil & PIB & $99.7 \pm 3.8$ & $(4)$ & -0.3 \\
DCE & Corn oil & $76.2 \pm 4.7^{d}(8)$ & -23.8 \\
DCE & PIB & $69.4 \pm 8.1^{d, e}(8)$ & -30.6 \\
\hline
\end{tabular}

${ }^{a}$ Male $\mathrm{B}_{6} \mathrm{C} 3 \mathrm{~F}_{1}$ mice were killed $4 \mathrm{hr}$ after ip administration of DCE $(200 \mathrm{mg} / \mathrm{kg})$ or corn oil. PIB $(200 \mathrm{mg} /$ $\mathrm{kg}$ ) was injected ip $1 \mathrm{hr}$ before DCE or corn oil.

${ }^{b}$ Values are $\bar{x} \pm S D$. The mean value for the fraction double-stranded DNA in the control group was 0.637 \pm 0.040 . Numbers of mice per group are in parentheses.

c Control minus treated.

${ }^{d}$ Significantly different from control $(p \leqslant 0.05)$ by one-way analysis of variance with multiple comparisons by the Bonferroni method (Neter and Wasserman, 1974).

e Significantly different from mice treated with DCE alone $(p \leqslant 0.05)$ by one-way analaysis of variance with multiple comparisons by the Bonferroni method (Neter and Wasserman, 1974). the total DNA recovered as double-stranded DNA. However, when mice were pretreated with PIB, the genotoxic effect of DCE was potentiated. The fraction of the total DNA recovered as double-stranded DNA, expressed as a percentage of control, was significantly decreased in the PIB-pretreated animals after DCE administration. Thus, it would appear that microsomal, cytochrome P-450-mediated, oxidative metabolism is not the primary source of the genotoxic metabolite(s) responsible for this type of DNA damage.

Previous studies of the metabolism of DCE in vivo in mice (Yllner, 1971) and rats (Reitz et al., 1982) indicated that oxidative metabolism is a major route of disposition for DCE. The identities of the major urinary metabolites recovered in these studies (chloroacetic acid, $S$-carboxymethylcysteine, thiodiacetic acid, and thiodiacetic acid sulfoxide) indicate that microsomal oxidative metabolism of DCE and subsequent conjugation of the oxidative metabolites with glutathione are involved in the generation of a significant fraction of these urinary metabolites. We have previously found significant depletion of hepatic glutathione levels in 
mice treatcd with DCE (Storer et al., 1982). Since this depletion is probably due largely to the conjugation of glutathione with oxidative metabolites of DCE, the assumed inhibitory effect of PIB on DCE metabolism should be evident as a decrease in the extent of hepatic glutathione depletion. This phenomenon has been observed in PIB-pretreated mice dosed with 1,2-dibromoethane (Kluwe et al., 1981). Results presented in Fig. 1 indicate that PIB pretreatment does significantly inhibit the glutathione depleting effect of DCF at $1 \mathrm{hr}$ after DCE administration but the magnitude of the effect is quite small. This may be evidence of a compensatory increase in the amount of DCE metabolized by the direct glutathione conjugation pathway after PIB pretreatment.

In the second series of experiments in this study, the in vivo genotoxicity of 2-chloroethanol was investigated. 2-Chloroethanol has been identified as a metabolite of DCE in

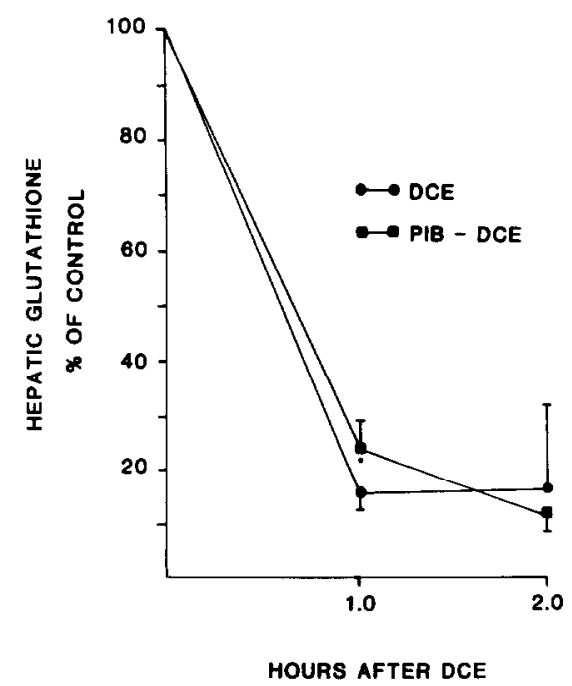

FIG. 1. Time course of hepatic glutathione depletion in male $\mathrm{B}_{6 \mathrm{C}} 3 \mathrm{~F}_{1}$ mice after ip injection of DCE (200 $\mathrm{mg} / \mathrm{kg}$ ) alone or with PIB pretreatment. PIB (200 mg/ $\mathrm{kg}$ ) was injected ip $1 \mathrm{hr}$ before DCE. Each point represents $\bar{X} \pm$ SD for 4 mice. *Significantly different from mice treated with DCE alone $(P \leqslant 0.05)$ by one-way analysis of variance. Control hepatic glutathione concentrations were $10.48 \pm 0.72(1 \mathrm{hr})$ and $9.05 \pm 0.9(2 \mathrm{hr}) \mu \mathrm{mol}$ glutathione $/ \mathrm{g}$ liver.

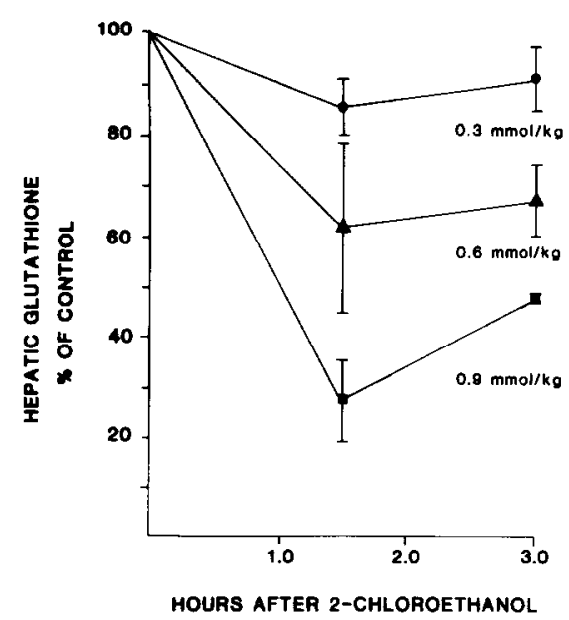

FIG. 2. Time course of hepatic glutathione depletion in male $\mathrm{B} 6 \mathrm{C} 3 \mathrm{~F}_{1}$ mice after ip injection of 2-chloroethanol. Each point represents the $\bar{X} \pm \mathrm{SD}$ for 4 male $\mathrm{B} 6 \mathrm{C}_{3} \mathrm{~F}_{1}$ mice. Control hepatic glutathione was $9.62 \pm 0.74 \mu \mathrm{mol} /$ g liver.

vitro (Guengerich et al., 1980) and has been shown to be a substrate for alcohol dehydrogenases (Johnson, 1967; Guengerich et al., 1979). Thus, in vivo administration of 2chloroethanol would be expected to lead to the formation of 2-chloroacetaldehyde intracellularly in hepatocytes, the major target cell population in this study. Since 2-chloroacetaldehyde is more readily conjugated with glutathione than 2-chloroethanol (Johnson, 1966), hepatic glutathione depletion is a convenient indicator of the extent of formation of 2-chloroacetaldehyde in vivo and was determined in these studies as a means of choosing appropriate dose levels for the in vivo genotoxicity experiments. Results presented in Fig. 2 indicate that hepatic glutathione levels are depleted below $30 \%$ of control values $1.5 \mathrm{hr}$ after a single ip dose of 0.9 $\mathrm{mmol} / \mathrm{kg}$ of 2-chloroethanol. Whereas the published $\mathrm{LD}_{50}$ for ip administration of 2chloroethanol to male mice is $1.2 \mathrm{mmol} / \mathrm{kg}$ (Lawrence et al., 1972), a range of dose levels from 0.9 to $1.2 \mathrm{mmol} / \mathrm{kg}$ was selected for the in vivo genotoxicity experiments.

The acute toxicity of 2-chloroethanol in this dose range was investigated in separate 
TABLE 4

ACUte Toxicity of 2-ChloRoethanol in B6C3F MALE MiCE $^{a}$

\begin{tabular}{|c|c|c|c|c|c|c|}
\hline Compound & Pretreatment & $\begin{array}{c}\text { Liver } \\
\text { weight }^{b}\end{array}$ & $\begin{array}{l}\text { Serum } \mathrm{IDH}^{c} \\
\quad(\mathrm{IU} / \mathrm{l})\end{array}$ & $\begin{array}{l}\text { Serum } A^{\prime} A T^{c} \\
(\text { IU/l) }\end{array}$ & $\begin{array}{l}\text { Kidney } \\
\text { weight }^{h}\end{array}$ & Mortality \\
\hline Saline & - & $4.74 \pm 0.28$ & $8.4 \pm 1.1$ & $5.4 \pm 2.5$ & $1.43 \pm 0.04$ & $0 / 6$ \\
\hline $\begin{array}{c}\text { 2-Chloroethanol, } \\
0.3 \mathrm{mmol} / \mathrm{kg}\end{array}$ & - & $4.43 \pm 0.32$ & $11.9 \pm 1.5$ & $4.8 \pm 1.9$ & $1.44 \pm 0.08$ & $0 / 3$ \\
\hline $\begin{array}{c}\text { 2-Chloroethanol, } \\
0.6 \mathrm{mmol} / \mathrm{kg}\end{array}$ & - & $4.40 \pm 0.06$ & $8.4 \pm 0.6$ & $2.9 \pm 0.5$ & $1.36 \pm 0.09$ & $0 / 3$ \\
\hline $\begin{array}{l}\text { 2-Chloroethanol, } \\
0.9 \mathrm{mmol} / \mathrm{kg}\end{array}$ & - & $4.53 \pm 0.09$ & $9.8 \pm 1.9$ & $5.1 \pm 0.3$ & $1.43 \pm 0.08$ & $0 / 3$ \\
\hline $\begin{array}{l}\text { 2-Chloroethanol, } \\
1.2 \mathrm{mmol} / \mathrm{kg}\end{array}$ & - & $5.52 \pm 0.52^{d}$ & $16.6 \pm 3.0^{d}$ & $17.8 \pm 8.8^{d}$ & $1.50 \pm 0.05$ & $0 / 5$ \\
\hline $\begin{array}{c}\text { 2-Chloroethanol, } \\
0.9 \mathrm{mmol} / \mathrm{kg}\end{array}$ & $\begin{array}{c}\text { Diethyl maleate } \\
3.0 \mathrm{mmol} / \mathrm{kg}\end{array}$ & $6.41 \pm 0.41^{d}$ & $34.7 \pm 1.7^{d}$ & $25.5 \pm 8.1^{d}$ & $1.49 \pm 0.06$ & $2 / 4$ \\
\hline $\mathrm{CCl}_{4}, 25 \mu \mathrm{l} / \mathrm{kg}$ & - & $6.23 \pm 0.53^{d}$ & $5821.0 \pm 1565.5^{d}$ & $2590.0 \pm 731.9^{d}$ & $1.51 \pm 0.09$ & $0 / 3$ \\
\hline
\end{tabular}

${ }^{a}$ Male $\mathrm{B} 6 \mathrm{C}_{3} \mathrm{~F}_{1}$ mice were killed $24 \mathrm{hr}$ after ip administration of $\mathrm{DCE}$, saline, or $\mathrm{CCl}_{4}$. Diethyl maleate was administered ip $1 \mathrm{hr}$ before 2-chloroethanol. All values are $\bar{x} \pm \mathrm{SD}$ for 3 to $6 \mathrm{~B} \mathrm{C} 3 \mathrm{~F}_{1}$ mice per group.

${ }^{b}$ Organ weight per $100 \mathrm{~g}$ body wt.

${ }^{c}$ IDH, L-iditol dehydrogenase (EC 1.1.1.14); AAT, alanine aminotransferase (EC 2.6.1.2).

${ }^{d}$ Significantly different from control, $(P \leqslant 0.05)$ by one-way analysis of variance with multiple comparisons by the Bonferroni method (Neter and Wasserman, 1974).

experiments. Results presented in Table 4 indicate that 2-chloroethanol was hepatotoxic only at the highest dose level tested, 1.2 $\mathrm{mmol} / \mathrm{kg}$. Pretreatment with DEM potentiated the acute toxicity of 2-chloroethanol indicating, as expected, a protective effect of glutathione. Mice pretreated with $3.0 \mathrm{mmol} /$ $\mathrm{kg}$ of diethyl maleate $1 \mathrm{hr}$ before $0.9 \mathrm{mmol} /$ $\mathrm{kg}$ of 2-chloroethanol experienced high mortality and significantly increased liver to body wcight ratios and serum enzyme activities.

The results of the in vivo genotoxicity experiments with 2-chloroethanol are presented in Table 5. Four hours after ip administration of 2-chloroethanol at doses as high as $1.2 \mathrm{mmol} / \mathrm{kg}$, there was no evidence of single-strand breaks and/or alkali-labile lesions in hepatic DNA. Pretreatment of mice with DEM to deplete hepatic glutathione prior to 2-chloroethanol administration also failed to produce a significant genotoxic effect. These results strongly suggest that 2-chloroethanol and 2-chloroacetaldehyde are not responsible for the hepatic DNA damage observed in these studies $4 \mathrm{hr}$ after DCE administration.

\section{DISCUSSION}

PIB is a potent inhibitor of cytochrome $P$ 450 monooxygenase activity. A methylenedioxyphenyl compound, it forms stable, metabolic intermediate complexes with cytochrome $P-450$ both in vitro and in vivo (Franklin, 1977). The potentiation of the in vivo genotoxicity of DCE observed after PIB pretreatment therefore suggests that either the overall flux of DCE through an alternate bioactivation pathway is increased or the 
TABLE 5

IN VIVO GENOTOXICITY OF 2-CHLOROETHANOL ${ }^{a}$

\begin{tabular}{|c|c|c|c|}
\hline Compound & Pretreatment & 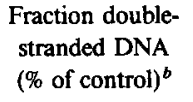 & $\begin{array}{c}\% \\
\text { Change }^{c}\end{array}$ \\
\hline Saline & - & $100.0 \pm 5.4(9)$ & \\
\hline $\begin{array}{c}\text { 2-Chloroethanol, } \\
0.9 \mathrm{mmol} / \mathrm{kg}\end{array}$ & - & $99.1 \pm 6.0(4)$ & -0.9 \\
\hline $\begin{array}{r}\text { 2-Chloroethanol, } \\
1.05 \mathrm{mmol} / \mathrm{kg}\end{array}$ & - & $99.4 \pm 4.1$ & -0.6 \\
\hline $\begin{array}{l}\text { 2-Chloroethanol, } \\
1.20 \mathrm{mmol} / \mathrm{kg}\end{array}$ & - & $104.1 \pm 6.8(5)$ & +4.1 \\
\hline $\begin{array}{c}\text { 2-Chloroethanol, } \\
0.9 \mathrm{mmol} / \mathrm{kg}\end{array}$ & $\begin{array}{l}\text { Diethyl } \\
\text { maleate, } 3.0 \\
\text { mmol } / \mathrm{kg}\end{array}$ & $97.8 \pm 9.4(5)$ & -2.2 \\
\hline
\end{tabular}

\footnotetext{
${ }^{a}$ Male B6C3F 1 mice were dosed ip with saline or 2-chloroethanol and killed $4 \mathrm{hr}$ later. Diethyl maleate was administered ip $1 \mathrm{hr}$ before 2-chloroethanol.

${ }^{b}$ Values are $\bar{x} \pm \mathrm{SD}$. The mean value for the fraction doublestranded DNA in the control group was $0.579 \pm 0.031$. Numbers of mice per group are in parentheses.

${ }^{c}$ Control minus treated.
}

activity of a detoxification pathway is decreased as a consequence of the inhibition of microsomal, cytochrome P-450-mediated, oxidative metabolism. However, since microsomal oxidative metabolism is not known to be involved in the detoxification of any of the known or suspected reactive metabolites of DCE, it would appear that the data indicate an enhanced activity of an alternate pathway of metabolic activation. The only other activation pathway for DCE that has been identified to date is the direct conjugation of DCE with glutathione mediated by the glutathione $S$-transferases. Thus, it would appear that the most plausible explanation for the potentiation of the in vivo genotoxicity of DCE observed after PIB pretreatment is an increase in the total amount of reactive metabolites generated by the glutathione conjugation pathway.

White et al. (1983) have recently shown that deuterium substitution inhibits the microsomal oxidative metabolism of 1,2-dibromoethane (DBE) in vitro and decreases its rate of clearance from the liver in vivo.
When the genotoxicities of DBE and tetradeutero-DBE were compared in an in vivo assay for single-strand breaks and alkali-labile lesions in DNA (alkaline elution), these authors found that the deuterium substitutions significantly increased the genotoxicity of DBE. They concluded, as we have here for DCE, that the increased genotoxicity, observed under conditions where microsomal oxidative metabolism was inhibited, strongly suggests that a product of the direct glutathione conjugation pathway is responsible for the hepatic DNA damage observed. The prolonged availability of $\mathrm{DBE}$ in the liver for glutathione conjugation was cited as a likely explanation for the potentiating effect of deuterium substitution. Thus, two, independent investigations of the role of microsomal oxidative metabolism in the in vivo genotoxicity of 1,2-dihaloethanes have produced similar results which suggest a primary role for active metabolites of the glutathione conjugation pathway in the production of the singlestrand breaks observed in alkaline DNA fragmentation assays. In addition, Ozawa and Guengerich (1983) have demostrated the formation of an $S$-[2-( $N^{7}$-guanyl)ethyl]glutathione adduct in DNA incubatcd with DBE, GSH, and glutathione $S$-transferases.

The negative results from the in vivo genotoxicity assays of 2-chloroethanol provide further evidence for the primary role of the glutathione conjugation pathway in the in vivo genotoxicity of DCE. The glutathione depleting effect of 2-chloroethanol in vivo strongly suggests the intracellular production of significant amounts of 2-chloroacetaldehyde since, as shown by Johnson (1966), 2chloroethanol itself is not a good substrate for glutathione $S$-transferase. The negative results might suggest that glutathione conjugation effectively detoxifies the 2-chloroacetaldehyde formed before it can diffuse to the nucleus, but no hepatic DNA damage was seen after pretreatment with $3.0 \mathrm{mmol} / \mathrm{kg}$ DEM. This pretreatment reduced the hepatic glutathione level to $30 \%$ of control values at 
$1 \mathrm{hr}$ (unpublished data) when the 2-chloroethanol was administered. Whereas this combined regimen was acutely toxic but showed no sign of a genotoxic effect, it seems unlikely that detoxification of 2-chloroacetaldehyde via the glutathione conjugation pathway could account for the negative results obtained in the genotoxicity experiments.

Guengerich et al. (1979, 1981) have demonstrated that 2-chloroacetaldehyde is the major alkylating agent involved in the irreversible binding of radiolabel to microsomal protein in in vitro experiments with vinyl chloride. Similar experiments with DCE demonstrated higher levels of binding of oxidative metabolites to microsomal protein than to DNA in in vitro systems (Guengerich et al., 1980). These results suggest that the majority of the 2-chloroacetaldehyde formed in vivo after administration of DCE or 2chloroethanol may be effectively trapped by glutathione and additional nucleophilic sites in proteins. Guengerich et al. (1981) have also demonstrated that the kinetics of 2chloroacetaldehyde binding to DNA are very slow. The failure of 2-chloroethanol to produce any evidence of DNA damage in our studies may, therefore, indicate that the concentration of 2-chloroacetaldehyde achieved in the nucleus is not sufficient to generate a significant quantity of DNA adducts.

A second possible explanation for the negative results obtained in the in vivo genotoxicity experiments with 2-chloroethanol is that the type of DNA damage produced by 2 chloroacetaldehyde may not be detected as single-strand breaks in alkali. If these lesions are not recognized by endonucleases involved in the excision-repair process, are not alkalilabile, or do not lead to the formation of alkali-labile lesions, then they would not be detected as single-strand breaks in this type of DNA damage assay. Thus, it is possible that microsomal oxidative metabolism of DCE to 2-chloroacetaldehyde may also be involved in the production of hepatic DNA damage in vivo.

\section{REFERENCES}

AKerboOM, T. P. M., AND SIES, S. (1981). Assay of glutathione, glutathione disulfide, and glutathione mixed disulfides in biological samples. In Methods in Enzymology (W. B. Jakoby, ed.), Vol. 77, pp. $373-$ 382. Academic Press, New York.

BanerJee, S., AND van DuUren, B. L. (1979). Binding of carcinogenic halogenated hydrocarbons to cell macromolecules. J. Natl. Cancer Inst. 63, 707-711.

BanerJee, S., Van DuUren, B. L., AND Oruambo, F. I. (1980). Microsome-mediated covalent binding of 1,2-dichloroethane to lung microsomal protein and salmon sperm DNA. Cancer Res. 40, 2170-2173.

Barbin, A.. Bresil, H., Croisy, A., Jacquignon, P., Malaveille, C., Montesano, R., and Bartsch, H. (1975). Liver microsome-mediated formation of alkylating agents from vinyl bromide and vinyl chloride. Biochem. Biophys. Res. Commun. 67, 596-603.

Barrio, J. R., SEcrist, J. A., AND Leonard, N. J. (1972). Fluorescent adenosine and cytidine derivatives. Biochem. Biophys. Res. Commun. 46, 597-604.

BlaIR, A. H., AND VALEE, B. L. (1966). Some catalytic properties of human liver alcohol dehydrogenase. Biochemistry 5, 2026-2034.

BONSE, G., URBan, T., ReICHERT, D., AND HeNSCHLER, D. (1975). Chemical reactivity, metabolic oxirane formation, and biological reactivity of chlorinated ethylene in the isolated perfused rat liver preparation. Biochem. Pharmacol. 24, 1829-1834.

Conney, A. H., Davison, C., Gastel, R., and Burns, J. J. (1960). Adaptive increases in drug-metabolizing enzymes induced by phenobarbital and other drugs. J. Pharmacol. Exp. Ther. 130, 1-8.

CONOlly, R. B., SzABo, S., AND JAEGER, R. J. (1979). Vinylidene fluoride: Acute hepatotoxicity in rats pretreated with PCB or phenobarbital. Proc. Soc. Exp. Biol. Med. 162, 163-169.

Franklin, M. R. (1977). Inhibition of mixed function oxidations by substrates forming reduced cytochrome P-450 metabolic-intermediate complexes. Pharmacol. Ther. A. 2, 227-245.

GREEN, T., AND HATHWAY, D. E. (1978). Interactions of vinyl chloride with rat liver DNA in vivo. Chem.Biol. Interact. 22, 211-224.

GRIFFITH, O. W. (1980). Determination of glutathione and glutathione disulfide using glutathione reductase and 2-vinylpyridine. Anal. Biochem. 106, 207-212.

Guengerich, F. P., CraWford, W. M., JR., AND WATANABE, P. G. (1979). Activation of vinyl chloride to covalently bound metabolites: Roles of 2-chloroethylene oxide and 2-chloroacetaldehyde. Biochemistry 18, 5177-5182.

Guengerich, F. P., Crawford, W. M., JR., DUMURADZK1, J. Y., MACDONALD, T. L., AND WATANABE, P. G. (1980). In vitro activation of 1,2-dichloroethane 
by microsomal and cytosolic enzymes. Toxicol. Appl. Pharmacol. 55, 303-317.

Guengerich, F. P., Mason, P. S., Stott, W. T., Fox, T. R., AND WATANABE, P. G. (1981). Roles of 2haloethylene oxides and 2-haloacetaldehydes derived from vinyl bromide and vinyl chloride in irreversible binding to protein and DNA. Cancer Res. 41, 43914398.

Hall, J. A., Saffhill, R., Green, T., and Hathway, D. E. (1981). The induction of errors during in vitro DNA synthesis following chloroacetaldehyde treatment of poly $(\mathrm{dA}-\mathrm{dT})$ and poly $(\mathrm{dC}-\mathrm{dG})$ templates. Carcinogenesis 2, 141-146.

HoOper, K., GOLD, L. S., AND AMES, B. N. (1980). The carcinogenic potency of ethylene dichloride in two animal bioassays: A comparison of inhalation and gavage studies. In Banbury Report 5: Ethylene Dichloride: A Potential Health Risk? (B. Ames, P. Infante, and R. Reitz, eds.), pp. 65-81. Cold Spring Harbor Laboratory, Cold Spring Harbor, New York.

JAMES, R. C., AND HARRISON, R. D. (1982). Hepatic glutathione and hepatotoxicity. Effects of cytochrome $P-450$ complexing compounds SKF 525-A, L- $\alpha$-acetylmethadol (LAAM), norLAAM, and piperonyl butoxide. Biochem. Pharmacol. 31, 1829-1835.

JoHNSON, M. K. (1966). Studies on glutathione $S$ alkyltransferase of the rat. Biochem. J. 98, 44-56.

JoHNSON, M. K. (1967). Metabolism of chloroethanol in the rat. Biochem. Pharmacol. 16, 185-199.

KAMIENSKI, F. X., AND MuRPiYY, S. D. (1971). Biphasic effects of methylene dioxyphenyl synergists on the action of hexobarbital and organophosphorus insecticides in mice. Toxicol. Appl. Pharmacol. 18, 883-894.

Kluwe, W. M., MCNiSh, R., SMIThSON, K., AND HooK, J. B. (1981). Depletion by 1,2-dibromoethane, 1,2-dibromo-3-chloropropane, Tris(2,3-dibromopropyl) phosphate, and hexachloro-1,3-butadiene of reduced non-protein sulfhydryl groups in target and non-target tissues. Biochem. Pharmacol. 30, 2265-2271.

LAIB, R. J., GWINNER, L. M., AND BOLT, H. M. (1981). DNA alkylation by vinyl chloride metabolites: Etheno derivatives or 7-alkylation of guanine? Chem.-Biol Interact. 37, 219-231.

Lawrence, W. H., Dillingham, E. O., Turner, J. E., AND AUTIAN, J. (1972). Toxicity profile of chloroacetaldehyde. J. Pharm. Sci. 61, 19-25.

LeE, C. H., AND WeTMuR, J. G. (1973). Physical studies of chloroacetaldehyde labelled fluorescent DNA. Biochem. Biophys. Res. Commun. 50, 879-885.

Maltoni, C., Valgimigli, L., and Scarnato, C. (1980). Long-term carcinogenicity bioassays on ethylene dichloride administered by inhalation to rats and mice. In Banbury Report 5: Ethylene Dichloride: A Potential Health Risk? (B. Ames, P. Infante, and R. Reitz, eds.), pp. 3-33. Cold Spring Harbor Laboratory, Cold Spring Harbor, New York.

MCCanN, J., Simmon, V., Streitweiser, D., aND
AMES, B. (1975). Mutagenicity of chloroacetaldehyde, a possible metabolic product of 1,2-dichloroethane, chloroethanol, vinyl chloride, and cyclophosphamide. Proc. Natl. Acad. Sci. USA 72, 3190-3193.

NaChTOMI, E., AND SARMA, D. S. R. (1977). Repair of rat liver DNA in vivo damaged by ethylene dibromide. Biochem. Pharmacol. 26, 1941-1945.

NeTER, J., AND WASSERMAN, W. (1974). Applied Linear Statistical Models. Irwin, Homewood, IIl.

OzaWa, N., AND Guengerich, F. P. (1983). Evidence for formation of an $S \cdot\left[2-\left(N^{7}\right.\right.$-guanyl)ethyl]glutathione adduct in glutathione-mediated binding of the carcinogen 1,2-dibromoethane to DNA. Proc. Natl. Acad. Sci. USA 80, 5266-5270.

Perocco, P., AND Prod, G. (1981). DNA damage by haloalkanes in human lymphocytes cultured in vitro. Cancer Lett. 13, 213-218.

Philpot, R. M., AND Hodgson, E. (1971/72). The production and modification of cytochrome $P-450$ difference spectra by in vivo administration of methylenedioxyphenyl compounds. Chem-Biol. Interact. 4, 185-194.

RANNUG, U. (1980). Genotoxic effects of 1,2-dichloroethane and 1,2-dibromoethane. Mutat. Res. 76, 269 295.

Rannug, U., Sundvall, A., and Ramel, C. (1978). The mutagenic effect of 1,2-dichloroethane on Salmonella typhimurium. I. Activation through conjugation with glutathione in vitro. Chem-Biol. Interact. 20, $1-16$

REITZ, R. H., FOX, T. R,, RAMSEY, J. C., QUAST, J. F., LANGVARDT, P. W., AND Watanabe, P. G. (1982). Pharmacokinetics and macromolecular interactions of ethylene dichloride in rats after inhalation or gavage. Toxicol. Appl. Pharmacol. 62, 190-204.

Sina, J. F., Bean, C. L., Dysart, G. R., Taylor, V. I., AND BRADLEY, M. O. (1983). Evaluation of the alkaline elution/rat hepatocyte assay as a predictor of carcinogenic potential. Mutat. Res. 113, 357-391.

StORER, R. D., Bank, P. A., AND CONOLly, R. B. (1982). In vivo genotoxic effect of 1,2-dichloroethane in male B6C3F1 mice. Toxicologist 2, 129.

StORER, R. D., AND ConOLly, R.B. (1983). Comparative in vivo genotoxicity and acute hepatotoxicity of three 1,2-dihaloethanes. Carcinogenesis 4, 1491-1493.

Storer, R. D., AND CONOLly, R. B. (1984). An in vivo-in vitro alkaline DNA unwinding assay for hepatic DNA damage: Comparison with the alkaline sucrose density gradient centrifugation technique. Anal. Biochem. 142, 351-359.

Storer, R. D., Jackson, N. M., AND CONOlly, R. B. (1984). In vivo genotoxicity and acute hepatotoxicity of 1,2-dichloroethane: Comparison of oral, intraperitoneal, and inhalation routes of exposure. Cancer Res. 44, 4267-4271.

TAN, E., AND HsIE, A. W. (1981). Mutagenicity and 
cytotoxicity of haloethanes as studied in the $\mathrm{CHO}-$ HGPRT system. Mutat. Res. 90, 183-191.

TIETZE, F. (1969). Enzymatic method for quantitative determination of nanogram amounts of total and oxidized glutathione: Application to mammalian blood and other tissues. Anal. Biochem. 27, 502-522.

U.S. Department of Health, Education, and Welfare, Public Health Sevice, National Institutes of Health, National Cancer Institute (1978). Bioassay of 1,2 Dichloroethane for Possible Carcinogenicity. (CAS No. 107-06-2). DHEW Publication (NIH)78-1361. U.S. Govt. Printing Office, Washington, D.C.

VAN Bladeren, P. J., Breimer, D. D., RotTeVeelSMIJS, G. M. T., DE KNIJFF, P., MOHN, G. R., VAN Meeteren-Walchi, B., Buigs, W., AND VaN DeR GEN, A. (1981). The relation between the structure of vicinal dihalogen compounds and their mutagenic activation via conjugation to glutathione. Carcinogenesis 2, 499-505.

VESELL, E. S. (1968). Factors altering the responsiveness of mice to hexobarbital. Pharmacology 1, 81-97.

White, R. D., GANDOLFi, A. J., Bowden, G. T., AND SIPES, 1. G. (1983). Deuterium isotope effect on the metabolism and toxicity of 1,2-dibromoethane. Toxicol. Appl. Pharmacol. 69, 170-178.

Wroblewski, F., AND LADUE, J. S. (1956). Serum glutamic-pyruvic transaminase in cardiac and hepatic disease. Proc. Soc. Fxp. Biol. Med. 91, 569-571.

YLLNER, S. (1971). Metabolism of 1,2-dichloroethane${ }^{14} \mathrm{C}$ in the mouse. Acta Pharmacol. Toxicol. 30, 257265. 